\title{
Nitrogen levels in the cultivation of strawberries in soilless culture
}

\author{
Jerônimo L Andriolo; Lígia Erpen; Francieli L Cardoso; Carine Cocco; Gustavo S Casagrande; Djeimi I \\ Jänisch \\ UFSM-Depto. Fitotecnia, 97105-900 Santa Maria-RS; ligia_erpen@yahoo.com.br; francyacecy@hotmail.com; carinecocco@yahoo. \\ com.br; gustavospreckelsen@hotmail.com; djeimi_agro@yahoo.com.br
}

\section{ABSTRACT}

In soilless grown strawberry crops, the nitrogen concentration of the nutrient solution affects plant growth and fruit yield and quality. The present research was conducted to determine the effect of nitrogen concentration in the nutrient solution on plant growth and development and fruit yield and quality of this crop. Treatments consisted of five nutrient solutions at nitrogen concentrations of 6.5 (T1), 8.0 (T2), 9.5 (T3), 11.0 (T4) and 12.5 (T5) $\mathrm{mmol} \mathrm{L}^{-1}$, in an entirely randomised experimental design with four replications. Ripe fruit yield was determined during the harvest period from June $6^{\text {th }}$ to November $27^{\text {th }}, 2009$. Number of leaves, shoot and root dry mass and crown diameter were determined at the later date. Number of leaves, shoot and root dry mass and crown diameter decreased by effect of increasing $\mathrm{N}$ concentrations in the nutrient solution. Fruit yield and fruit size fitted a polynomial model, with maximum values at $8.9 \mathrm{mmol} \mathrm{N} \mathrm{L}^{-1}$. The $\mathrm{N}$ concentration used for the strawberry crop in soilless growing systems can be reduced to $8.9 \mathrm{mmol} \mathrm{L}^{-1}$ without any reduction in fruit yield.

Keywords: Fragaria $x$ ananassa, hydroponics, mineral nutrition of plants.

\section{RESUMO}

\section{Doses de nitrogênio no cultivo fora do solo do morangueiro}

No cultivo sem solo do morangueiro, a concentração de nitrogênio da solução nutritiva afeta o crescimento da planta, a produtividade e a qualidade das frutas. O objetivo do trabalho foi determinar o efeito da concentração de nitrogênio da solução nutritiva no crescimento e desenvolvimento da planta e produção de frutas do morangueiro. Os tratamentos foram constituídos por cinco concentrações de $\mathrm{N}$ na solução nutritiva: 6,5 (T1), 8,0 (T2), 9,5 (T3), 11,0 (T4) e 12,5 (T5) $\mathrm{mmol} \mathrm{L}{ }^{-1}$, em delineamento experimental inteiramente casualizado, com quatro repetições. Foi determinada a produção de frutas no período entre 6 de junho e 27 de novembro de 2009, o número de folhas e a massa seca da parte aérea, coroas e raízes na última data. O número de folhas, a massa seca da parte aérea e das raízes e o diâmetro da coroa diminuíram com o aumento da concentração de $\mathrm{N}$ na solução nutritiva. A produção e o tamanho das frutas apresentaram resposta polinomial, com ponto de máxima na concentração de 8.9 mmol L-1 . Concluiu-se que a concentração de $\mathrm{N}$ atualmente empregada na produção dessa cultura em sistemas fora do solo pode ser reduzida para $8.9 \mathrm{mmol} \mathrm{L}^{-1}$, sem redução na produtividade de frutas.

Palavras-chave: Fragaria $x$ ananassa, hidroponia, nutrição mineral de plantas.

(Recebido para publicação em 6 de agosto de 2010; aceito em 13 de outubro de 2011) (Received on August 6, 2010; accepted on October 13, 2011)

$\mathrm{T}$ he soil cropping system traditionally used for the production of the strawberry crop in Southern Brazil is nowadays changing to soilless cultivation. Main reasons for this new technological step is saving labour and searching for better ergonometric conditions for workers, especially during fruit harvesting.

In soilless grown plants, the concentration of the nutrient solution has to be adapted to the plant species and local environmental conditions. Strong variations in nutrient concentrations used for the strawberry crop have been reported in the literature (Gimenez et al., 2008). For nitrogen, total concentrations were between $4.7 \mathrm{mmol} \mathrm{L}^{-1}$ (Paranjpe et al., 2003), $14.0 \mathrm{mmol} \mathrm{L}^{-1}$ (Hennion \& Veschambre, 1997) and $14.3 \mathrm{mmol} \mathrm{L}^{-1}$ (Tabatabaei et al., 2008). In Southern
Brazil, the nutrient solution for this crop was adjusted to a total nitrogen concentration of $10.2 \mathrm{mmol} \mathrm{L}^{-1}$ and a $\mathrm{K}^{+} /\left(\mathrm{Ca}^{+2}+\mathrm{Mg}^{+2}\right)$ ratio of 1.17 to reduce the number of fertilizers used in its preparation and production costs (Andriolo, 2007).

Nitrogen is a key nutrient in crop growth and yield, because it affects photosynthesis and dry matter partitioning among organs (Yin et al., 2003). In strawberry plants, nitrogen deficiency reduces carbon allocation to fruits, fruit number and yield and increases fruit weight ratio (Deng \& Woodward, 1998). Nitrate uptake rate of strawberry plants was enhanced by increasing the nitrate concentration of the nutrient solution from 3.75 to $15 \mathrm{mM} \mathrm{L}^{-1}$, but growth and fruit yield were not affected (Darnell \& Stutte,
2001). In soilless growing plants using organic substrates, neither early nor total marketable yield was significantly affected by $\mathrm{N}$ level or type of soilless media. However, soluble solids were decreased with increasing $\mathrm{N}$ level and it was concluded that total $\mathrm{N}$ concentrations as low as $2.8 \mathrm{mmol}$ $\mathrm{L}^{-1}$ can be used for this crop in open soilless growing systems (Cantliffe et al., 2007). It was also hypothesized that strawberry growth and yield was limited by its ability to reduce and assimilate nitrate into tissues and not by its ability to uptake nitrate. In strawberry crops grown in soil under high nitrogen fertilization rates, plant vigour was increased while flowering, fruit yield and quality were reduced (Passos, 1999; Otto et al., 2009). Similar data for soilless strawberry Brazilian crops were 
not found in the literature.

Reducing the nutrient concentration of the nutrient solutions is also a current task for economical and environmental reasons. Fertilizer prices have been increasing in recent years and this crop risks lack profitability in soilless culture. Growing systems in use are mainly of the open type, discharging in the environment the drained nutrient solutions. This practice is being more and more criticized, especially for $\mathrm{NO}_{3}^{-}$ ions. Such constraints can be minimized by lowering the nutrient concentrations of the nutrient solution. However, a critical $\mathrm{N}$ concentration should be determined to prevent reduction in plant growth and fruit yield and quality.

The objective of this research was to determine the effect of nitrogen rates on growth and development, fruit yield and quality of soilless grown strawberry plants.

\section{MATERIAL AND METHODS}

The experiment was conducted from April $24^{\text {th }}$ to November $27^{\text {th }} 2009$, inside a polyethylene greenhouse at Departamento de Fitotecnia, UFSM. Average air temperatures and global solar radiation were, respectively: $20.6^{\circ} \mathrm{C}$ and 15.3 $\mathrm{MJ} \mathrm{m}^{-2}$ day $^{-1}$ in April; $17.9^{\circ} \mathrm{C}$ and 17.4 $\mathrm{MJ} \mathrm{m}^{-2}$ day $^{-1}$ in May; $12.7^{\circ} \mathrm{C}$ an 9.6 $\mathrm{MJ} \mathrm{m}^{-2}$ day $^{-1}$ in June; $11.9^{\circ} \mathrm{C}$ and $9.9 \mathrm{MJ}$ $\mathrm{m}^{-2}$ day $^{-1}$ in July; $17.3^{\circ} \mathrm{C}$ and $12.0 \mathrm{MJ}$ $\mathrm{m}^{-2}$ day $^{-1}$ in August; $16.7^{\circ} \mathrm{C}$ and 11.8 $\mathrm{MJ} \mathrm{m}^{-2}$ day $^{-1}$ in September; $19.5^{\circ} \mathrm{C}$ and 19.5 $\mathrm{MJ} \mathrm{m}^{-2}$ day $^{-1}$ in October; $27.8^{\circ} \mathrm{C}$ and $14.1 \mathrm{MJ} \mathrm{m}^{-2}$ day $^{-1}$ in November. The closed hydroponic system was used, constituted by a sand (0.001-0.03 m gauge, $1.6 \mathrm{~kg} \mathrm{dm}^{-3}$ bulk density and $0.111 \mathrm{~L} \mathrm{dm}^{-3}$ maximum water retention capacity) growing bed over fibber cement tiles, at $0.80 \mathrm{~m}$ height above the soil. The nutrient solution from a polyethylene reservoir was supplied eight times a day for $15 \mathrm{~min}$ to the growing bed by sub-irrigation, to assure optimal water and nutrient availability to plants (Andriolo, 2007).

The nutrient solution reported by Hennion \& Veschambre (1997) for strawberry fruit production was used as reference, with nutrient concentrations adjusted to, in mmol L-1, $9.2 \mathrm{NO}_{3}^{-} ; 0.3$ and $1 \mathrm{SO}_{4}^{-2}$ (Table 1). Micronutrients were, in $\mathrm{mg} \mathrm{L}^{-1}, 0.03 \mathrm{Mo} ; 0.42 \mathrm{~B} ; 0.06$ $\mathrm{Cu} ; 0.50 \mathrm{Mn} ; 0.22 \mathrm{Zn}$ and 1.0 Fe. The electrical conductivity (EC) was $1.5 \mathrm{dS}$ $\mathrm{m}^{-1}$ and $\mathrm{pH}$ 5.9.

Treatments were five total $\mathrm{N}$ concentrations in the nutrient solution: 6.5 (T1), 8.0 (T2), 9.5 (T3), 11.0 (T4) and 12.5 (T5) mmol L-1 (Table 1). The entirely randomised experimental design was used, with four replications and 12 plants per plot in separated sand growing beds. Fertilizers were potassium nitrate $\left(38.7 \% \mathrm{~K}^{+}\right.$and $\left.13.8 \% \mathrm{~N}_{-} \mathrm{NO}_{3}{ }^{-}\right)$, ammonium nitrate $(35.0 \% \mathrm{~N})$, calcium nitrate-calcinit ${ }\left(14.4 \% \mathrm{~N}-\mathrm{NO}_{3}^{-}, 1.1 \%\right.$ $\mathrm{N}-\mathrm{NH}_{4}^{+}$and $19 \% \mathrm{Ca}^{+2}$ ), potassium monophosphate-MKP® $\left(28.7 \% \mathrm{~K}^{+}\right.$ and $\left.22.8 \% \mathrm{H}_{2} \mathrm{PO}_{4}^{-}\right)$, potassium sulphate $\left(44.9 \% \mathrm{~K}^{+}\right.$and $\left.18.4 \% \mathrm{SO}_{4}{ }^{-2}\right)$ and magnesium sulphate $\left(9.9 \% \mathrm{Mg}^{+2}\right.$ and $\left.18.4 \% \mathrm{SO}_{4}^{-2}\right)$. Nitrogen concentrations were differed by modifying potassium nitrate, ammonium nitrate, potassium monophosphate and potassium sulphate quantities in the nutrient solution. Ionic ratios among nutrients and fertilizer quantities were calculated as described in Andriolo (1999). The EC and pH were daily measured and corrections were done whenever necessary to maintain within the limits of 1.0 and $1.5 \mathrm{dS} \mathrm{m}^{-1}$ and 5.5 and 6.5 , respectively.

Transplants of the strawberry cultivar Arazá (INIA, Uruguay) were used, produced from runner tips grown in 128 cell-trays. Planting was done at April $24^{\text {th }}, 2009$, in a density of 14 plants $/ \mathrm{m}^{2}$. Crop management was as recommended by Antunes \& Duarte Filho (2005). Ripe fruits were harvested twice a week, at the 87 phenological stage (Meier et al., 1994), counted and $\mathrm{NH}_{4}^{+} ; 3.0 \mathrm{H}_{2} \mathrm{PO}_{4}^{-} ; 7 \mathrm{~K}^{+} ; 2.0 \mathrm{Ca}^{+2} ; 1 \mathrm{Mg}^{2+}$

weighed. Soluble solids and acidity of fruits were determined at the Post Harvest Laboratory. The experiment was ended 27 November 2009, and four plants in plots of each treatment were harvested, the crown diameter measured and dry mass of shoot and roots determined after drying at $65^{\circ} \mathrm{C}$ until constant mass was reached. Results were submitted to analysis of variance and polynomial regression using the software Sisvar (UFLA, version 4.2).

\section{RESULTS AND DISCUSSION}

The number of leaves on the plant decreased by effect of $\mathrm{N}$ levels, following a polynomial model (Figure 1a). The higher number was 44 leaves/ plant at $6.5 \mathrm{mmol} \mathrm{L}^{-1}$ (T1) and the lower one was 31 leaves plant ${ }^{-1}$ at $11.5 \mathrm{mmol}$ $\mathrm{L}^{-1}$ (T5), a decrease of $29.5 \%$. Similar trend was observed in shoot growth, decreasing from $10.5 \mathrm{~g} / \mathrm{plant}$ in $\mathrm{T} 1$ to $6.0 \mathrm{~g} /$ plant in T5 (Figure 1b). The effect on shoot growth may be a consequence of the number of leaves in leaf area index (LAI) and photosynthesis, as demonstrated in the literature for several plant species (Yin et al., 2003). Root growth decreased following a polynomial model (Figure 2a) and a linear regression was also fitted between shoot and root growth $(\mathrm{RG}=0.36 \mathrm{SG}+$ $1.27, \mathrm{R}^{2}=0.84^{*}$, figure not shown).

The relationship between root and shoot growth can be attributed to the dynamics of the shoot:root ratio on plant growth, as described in other species (Andrews et al., 2006), and reinforces the above hypothesis of lower $\mathrm{CO}_{2}$ assimilation on plants under higher $\mathrm{N}$ availability. The plant crown diameter decreased linearly (Figure 2b) and may

Table 1. Ionic concentrations of nutrient solutions used as treatments (concentração iônica das soluções nutritivas empregadas como tratamentos). Santa Maria, UFSM, 2010.

\begin{tabular}{lcccccccc}
\hline \multirow{2}{*}{ Treatments } & \multicolumn{7}{c}{ Ion concentration $\mathbf{( m m o l} / \mathbf{L})$} \\
\cline { 2 - 9 } & $\mathbf{N O}_{3}^{-}$ & $\mathbf{H}_{2} \mathbf{P O}_{4}^{-}$ & $\mathbf{S O}_{4}^{-2}$ & $\mathbf{K}^{+}$ & $\mathbf{C a}^{+2}$ & $\mathbf{M g}^{+2}$ & $\mathbf{N H}_{4}^{+}$ & Total N \\
\hline $\mathrm{T} 1$ & 6.2 & 3.0 & 2.5 & 7.0 & 2.0 & 1.0 & 0.3 & 6.5 \\
$\mathrm{~T} 2$ & 7.7 & 3.0 & 1.75 & 7.0 & 2.0 & 1.0 & 0.3 & 8.0 \\
$\mathrm{~T} 3$ & 9.2 & 3.0 & 1.0 & 7.0 & 2.0 & 1.0 & 0.3 & 9.5 \\
$\mathrm{~T} 4$ & 9.9 & 3.0 & 1.0 & 7.0 & 2.0 & 1.0 & 1.1 & 11.0 \\
$\mathrm{~T} 5$ & 10.7 & 2.0 & 1.0 & 6.0 & 2.0 & 1.0 & 1.8 & 12.5 \\
\hline
\end{tabular}




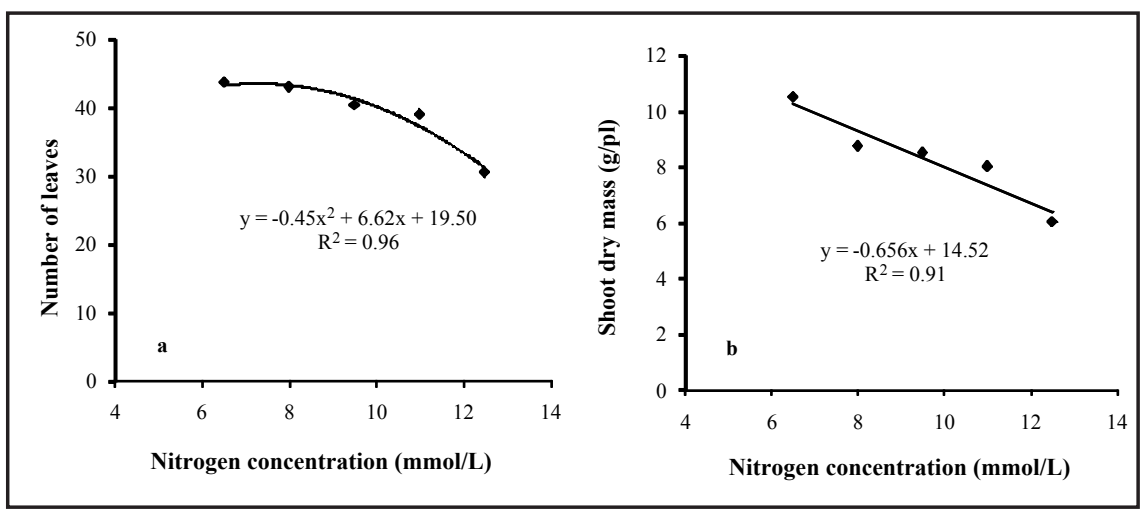

Figure 1. Number of leaves (a) and shoot dry mass (b) of strawberry plants grown under nitrogen concentrations from 6.5 to $12.5 \mathrm{mmol} / \mathrm{L}$ in the nutrient solution (número de folhas (a) e massa seca (b) da parte aérea de plantas de morangueiro cultivadas sob concentrações de nitrogênio de 6,5 a 12,5 mmol/L na solução nutritiva). Santa Maria, UFSM, 2010.

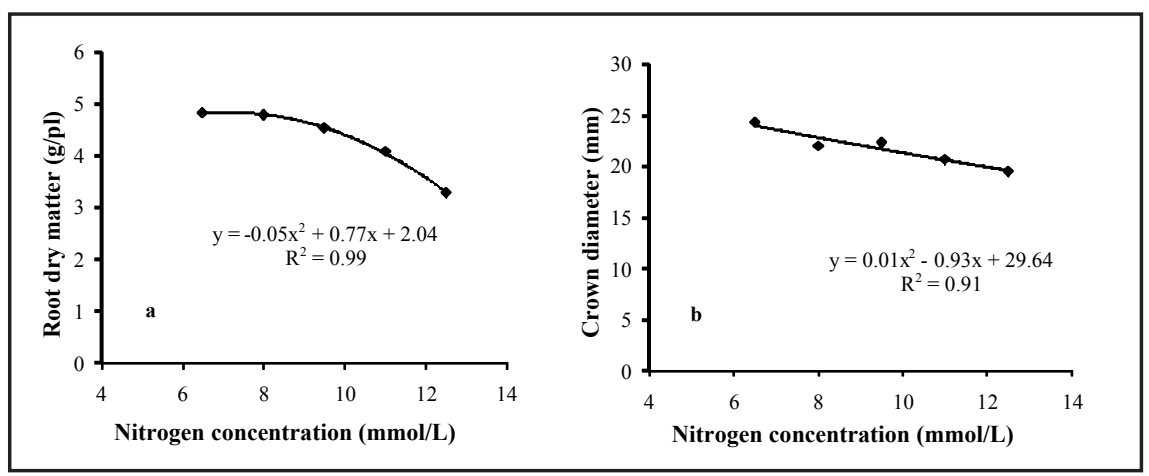

Figure 2. Root dry matter (a) and crown diameter (b) of strawberry plants grown under nitrogen concentrations from 6.5 to $12.5 \mathrm{mmol} / \mathrm{L}$ in the nutrient solution (massa seca de raízes (a) e diâmetro de coroa (b) de plantas de morangueiro cultivadas sob concentrações de nitrogênio de 6,5 a 12,5 mmol/L na solução nutritiva). Santa Maria, UFSM, 2010.
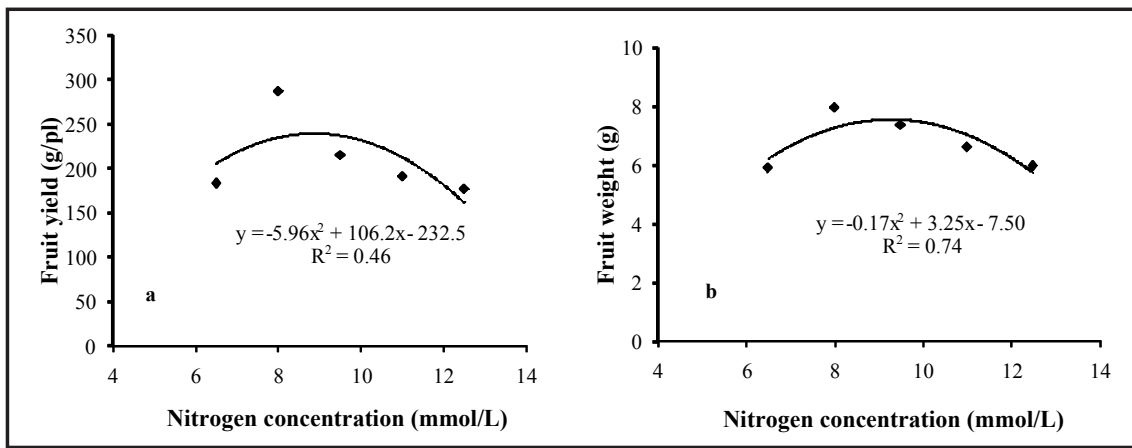

Figure 3. Fruit yield (a) and fruit weight (b) of strawberry plants grown under nitrogen concentrations from 6.5 to $12.5 \mathrm{mmol} / \mathrm{L}$ in the nutrient solution (produção de frutos (a) e peso de frutos (b) de plantas de morangueiro cultivadas sob concentrações de nitrogênio de 6,5 a 12,5 mmol/L na solução nutritiva). Santa Maria, UFSM, 2010.

be a consequence of lower availability of assimilates originated by lower number of leaves and leaf area index. Number of fruits and crowns was similar among treatments and average values were 31 fruits/plant and 4 crowns/plant.

Fruit yield (Figure 3a) and weight (Figure $3 b$ ) decreased following a were $6.3^{\circ}$ Brix and $1.53 \mathrm{~N}$, respectively. These results were lower than those reported by Fernandes Júnior et al. (2002) in São Paulo and similar to those of Andriolo et al. (2009) at an EC of $3.8 \mathrm{dS} \mathrm{m}^{-1}$.

Present results about the effect of $\mathrm{N}$ concentration in soilless growing strawberries differ from the literature. In a similar research with $\mathrm{N}$ concentrations between $2.8 \mathrm{mmol} \mathrm{L}^{-1}$ and $11.4 \mathrm{mmol}$ $\mathrm{L}^{-1}$ and pine bark and coconut coir as substrates, Cantlife et al. (2007) reported no effect on number of leaves, crown diameter, early and total fruit yield, but lower soluble solids at higher $\mathrm{N}$ concentrations. They concluded that $\mathrm{N}$ level in the nutrient solution can be lowered from $2.8 \mathrm{mmol} \mathrm{L}^{-1}$ to $5.7 \mathrm{mmol}$ $\mathrm{L}^{-1}$ without reduction in yield and in fruit quality, irrespective of the substrate. In fact, this might be an indirect effect of the EC of the nutrient solution. When the $\mathrm{N}$ concentration of the nutrient solution is increased, its EC is also increased. In a previous experiment at the same site and similar conditions, strawberry plant growth and fruit yield decreased when the EC of the nutrient solution was increased from 0.9 to 3.2 $\mathrm{dS} \mathrm{m}{ }^{-1}$ (Andriolo et al. 2009). As a consequence, the positive effects of $\mathrm{N}$ on growth might be counterbalanced by negative ones of the increase in the EC.

Emission of leaves and inflorescences in the strawberry plant has been related mainly to temperature and photoperiod (Serçe \& Hancock, 2005). It's unlikely a direct effect of $\mathrm{N}$ rates on plant developmental variables of this crop. Nevertheless, it may affect the lifetime of leaves. In Fragaria chiloensis, increasing leaf death under high $\mathrm{N}$ levels has been reported (Alpert, 1991). Lesser leaves on the plant reduces LAI and photosynthesis and, consequently, vegetative growth and fruit yield. This hypothesis is also supported by fruit acidity, as low strawberry fruit quality has been reported under high temperature (Cantlife et al., 2007).

The above hypothesis is reinforced by number of fruits on the plant, which was similar among all treatments. This implies that fruit set was not affected and fruit yield was a consequence of fruit weight (Figure 3a, b). Another 


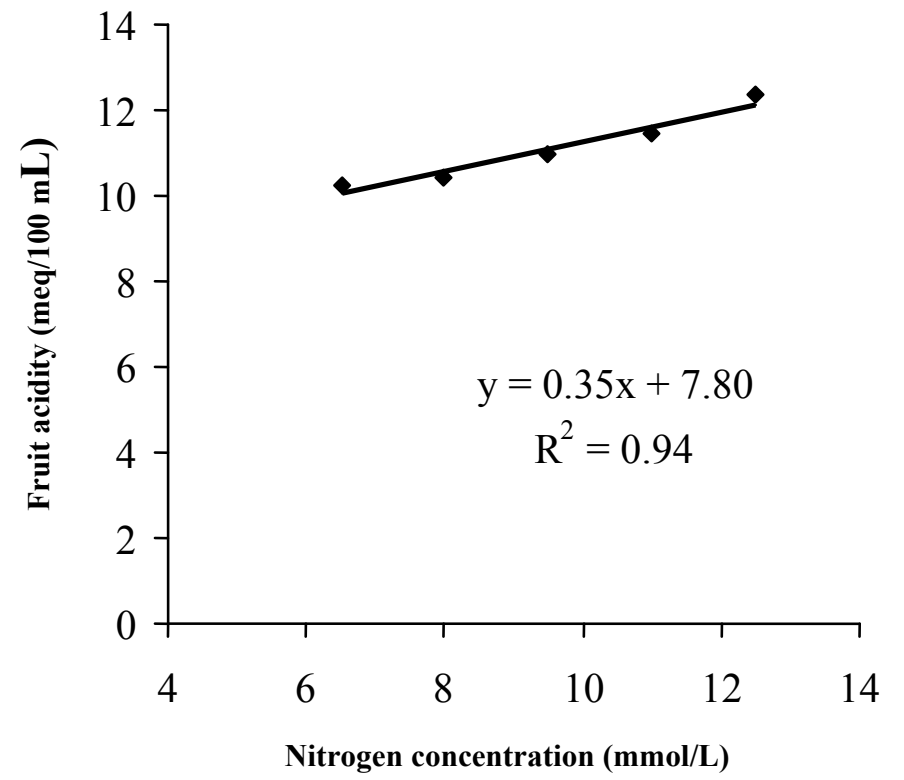

Figure 4. Fruit acidity of strawberry plants grown under nitrogen concentrations from 6.5 to $12.5 \mathrm{mmol} / \mathrm{L}$ in the nutrient solution (acidez de frutas de morangueiro sob concentrações de nitrogênio de 6,5 a 12,5 mmol/L na solução nutritiva). Santa Maria, UFSM, 2010.

hypothesis is that increasing levels of $\mathrm{NO}_{3}^{-}$depress fruit growth. In fact, Tabatabaei et al. (2008) reported that fruit yield was increased 39\% when the nutrient solution concentration contained $14.3 \mathrm{mmol} \mathrm{L}^{-1} \mathrm{NO}_{3}^{-}$was split in 75:25 or $50: 50 \mathrm{NO}_{3}^{-}: \mathrm{NH}_{4}^{+}$ratio. In our experiment, $\mathrm{NO}_{3}^{-}: \mathrm{NH}_{4}^{+}$ratios were as high as 90:10 in T1, 93:07 in T2, 94:06 in T3, 94.6:5.4 in T4 and 80:20 in T5. Thus the hypothesis of growth and fruit yield being depressed by $\mathrm{NO}_{3}^{-}$may also be taken into account.

Technological implications can be drawn from present results. The total $\mathrm{N}$ concentration in the current nutrient solutions used for the strawberry crop in soilless growing systems in Brazil can be reduced to $8.9 \mathrm{mmol} \mathrm{L}^{-1}$ without any reduction in fruit yield, with economical and environmental benefit consequences. The effect of splitting the total $\mathrm{N}$ concentration in a $\mathrm{NO}_{3}^{-}$ $: \mathrm{NH}_{4}^{+}$ratio on plant growth and yield under local environmental conditions must be the issue of new researches in the management of this crop in soilless growing systems.

\section{ACKNOWLEDGEMENTS}

To Conselho Nacional de Desenvolvimento Científico e Tecnológico (CNPq), for Grant $n^{\circ}$ 470177/2006-3 and to Fundação de Amparo a Pesquisa do RS (FAPERGS), Grant $n^{\circ} 08510544$.

\section{REFERENCES}

ALPERT P. 1991. Nitrogen sharing among ramets increases clonal growth in Fragaria chiloensis. Ecology 72: 69-80

ANDREWS M. 2006. A role for shoot protein in shoot-root dry matter allocation in higher plants. Annals of Botany 97: 3-10.

ANDRIOLO JL. 1999. Fisiologia das culturas protegidas. Santa Maria: UFSM.142p.

ANDRIOLO JL. 2007. Preparo e manejo da solução nutritiva na produção de mudas e de frutas do morangueiro. In: SEMINÁRIO SOBRE O CULTIVO HIDRÔPONICO DE MORAnGUEIRO. Proceedings...Santa Maria: UFSM. p. 41-50.

ANDRIOLO JL et al. 2009. Concentração da solução nutritiva no crescimento da planta, na produtividade e na qualidade de frutas do morangueiro. Ciência Rural 39: 684-690. ANTUNES LEC; DUARTE FILHO J. 2005.
Sistema de produção do morango. Produção de mudas. Sistemas de produção 5. EMBRAPA CT. Available from: http://www.cpact. embrapa/sistema/morango. Accessed on January 20, 2008.

CANTLIFFE DJ et al. 2007. Yield and quality of greenhouse-grown strawberries as affected by nitrogen level in coco coir and pine bark media. Proceedings of the Florida State Horticultural Society 120: 157-161.

DARNELL RL; STUTTE GW. 2001. Nitrite concentration effects on $\mathrm{NO}_{3}-\mathrm{N}$ uptake and reduction, growth, and fruit yield in strawberry. Journal of the American Society for Horticultural Science 126: 560-563.

DENG X; WOODWARD FI. 1998. The growth and yield responses of Fragaria ananassa to elevated $\mathrm{CO}_{2}$ and N Supply. Annals of Botany 81: 67-71.

FERNANDES-JÚNIOR F et al. 2002. Produção de frutos e estolhos do morangueiro em diferentes sistemas de cultivo em ambiente protegido. Bragantia 61: 25-34.

GIMENEZ G. 2008. Cultivo sem solo do morangueiro. Ciência Rural 38: 273-279.

HENNION B; VESCHAMBRE D. 1997. La fraise: maîtrise de la production. Paris: CTIFL, 299 p.

MEIER U et al. 1994. Phänologische Entwicklungsstadien des Kernobstes (Malus domestica Borkh. und Pyrus communis L.), des Steinobstes (Prunus-Arten), der Johannisbeere (Ribes-Arten) und der Erdbeere (Fragaria $x$ ananassa Duch.). Nachrichtenbl. Deutchland Pflanzenschutz 46: 141-153.

OTTO RF et al. 2009. Cultivares de morango de dia neutro: produção em função de doses de nitrogênio durante o verão. Horticultura Brasileira 27: 217-221.

PARANJPE A et al. 2003. Winter strawberry production in greenhouses using soilless substrates: an alternative to methyl bromide soil fumigation. Proceedings of the Florida State Horticultural Society 116: 98-105.

PASSOS FA. 1999. Nutrição, adubação e calagem do morangueiro. In: DUARTE FILHO J; CANÇADO GMA; REGINA MA; ANTUNES LEC; FADINI MAM. (coord). Morango: tecnologia de produção e processamento. Caldas : Epamig. p. 159-167.

SERÇE S; HANCOCK JF. 2005. The temperature and photoperiod regulation of flowering and runnering in the strawberries, Fragaria chiloensis, F. virginiana, and $F$. x ananassa. Scientia Horticulturae 103: 167-177.

TABATABAEI SJ et al. 2008. Effects of shading and $\mathrm{NO}_{3}: \mathrm{NH}_{4}$ ratio on the yield, quality and $\mathrm{N}$ metabolism in strawberry. Scientia horticulturae 116: 264-272.

YIN X et al. 2003. Some quantitative relationships between leaf area index and canopy nitrogen content and distribution. Annals of Botany 91: 893-903. 